\title{
THE ROAD NETWORK PERMEABILITY AT CONFLICT POINTS WITH WILDLIFE CORRIDORS: DETAILED STUDY OF THE CROSS-BORDER AREA BESKYDY - KYSUCE
}

\author{
Ivo Dostál, Josef Svoboda, Pavel Pohorský, Marek Havlíček
}

\begin{abstract}
The permeability of 1 st and 2nd class roads was analysed in 38 locations distributed over the model area covering cross-border region between the Czech and Slovak Republic. To better understand the barrier effect of these types of roads, an extensive monitoring of traffic flow was carried out at selected locations and subsequently, its distribution patterns were analysed with emphasis on nighttime. The work has been performed within the Transgreen project (Interreg Danube programme; no. DTP1-187-3.1-TRANSGREEN). The general results confirmed that 1st class roads included in European system have very limited permeability while other roads are more or less permeable for the major part of the night and at the intensity around 1,500 vehicles per day even during the daytime.
\end{abstract}

Keywords: road network, permeability, wildlife corridor, Beskydy, Kysuce, Transgreen

\section{Introduction}

One of major existing threats to wildlife populations is the anthropogenic fragmentation, caused by growing built-up areas, economical activities and linear transport infrastructure such as roads, railway lines, inland navigation channels, etc. (Iuell et al., 2003; Anděl, 2013). The limited patches of preserved undisturbed landscape with no connection to other patches due to barrier effect than became unsuitable to host local populations of certain species which can even extinct. This long-term process is emerging also in the Czech Republic (Anděl et al., 2010, Dostál et al., 2018).

The flagship of ecological research in relation to the transport infrastructure are so called umbrella species - in our case the large carnivores such as the brown bear (Ursus arctos), the wolf (Canis lupus) and European lynx (Lynx lynx). Ensuring road's permeability for these species with high ecological demands gives the assumption of sufficient permeability also for other species. In Central and Eastern Europe, they are key animal species that are being studied for migration and the presence of barriers to the road network. Kusak et al. (2009) studied the permeability of motorway in Gorski kotar (Croatia) for large mammals. In many Central and Eastern European countries, there are still high value landscapes due to 
their habitat quality. Environmental assessments mandatory for road constructions in the EU do not necessarily require explicit measures for the mitigation of fragmentation and the effectivity of measures is not regularly monitored. Kaphegyi et al. (2013) evaluated technical structures at two sections of the motorway separating relevant subpopulations of the brown bear (Ursus arctos) in Bulgaria. They found that the potential for improvement of the permeability of already existing technical facilities along the motorways is very limited.

\section{Model area and research localities}

The transboundary pilot area Kysuce - Beskydy is situated on the border between the Czech Republic and the Slovak Republic. This area belongs to the Carpathians, the largest mountain region in Europe. It is the home of all three carnivore species and the westernmost site to host their Carpathian populations (Chapron et al., 2014). The complicated orography of the region predetermined the most suitable routes for transport networks - their directions followed the valleys of main rivers embedded in mountain ranges. Other human activities were also concentrated in these favourable places and formed barriers which can be hardly surpassed by wildlife.

Figure 1: Distribution of localities under study throughout model area

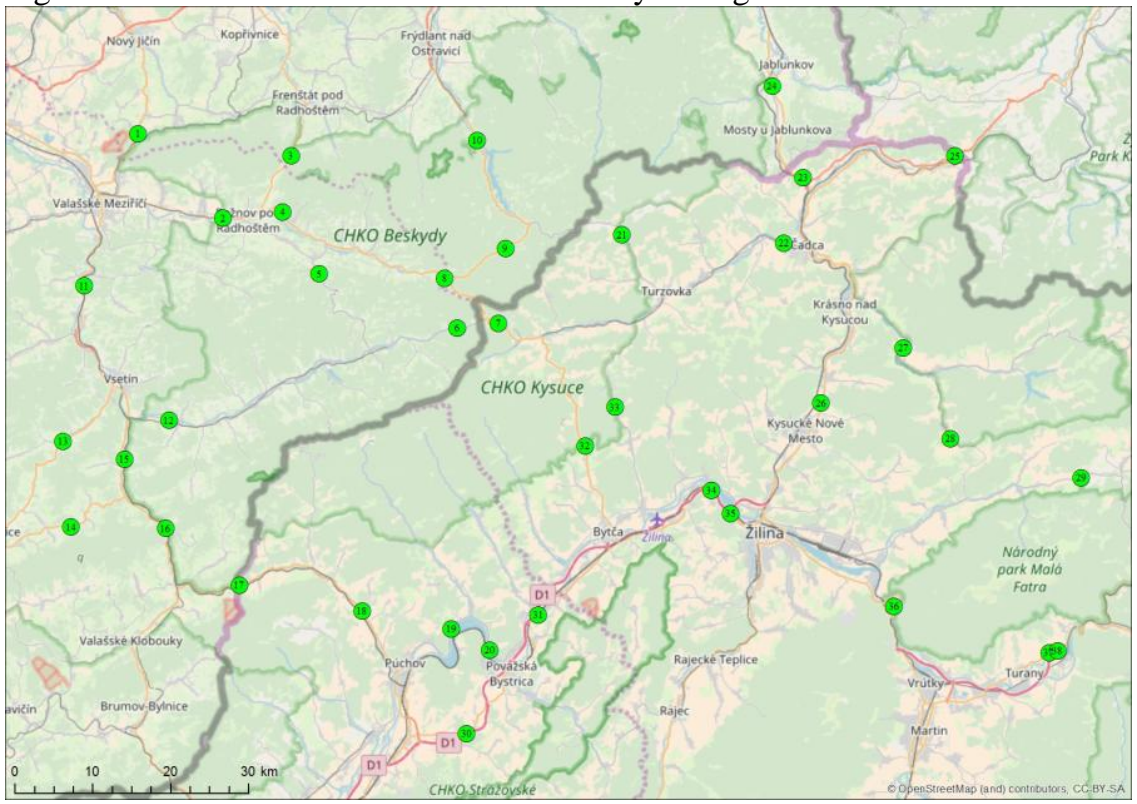

Source: authors' own work; background map: COpenStreetMap 
The research was undertaken in 38 localities (Figure 1) of which 16 are situated in the Czech Republic and 22 in Slovakia. They were divided into three basic groups in dependence of road category: 10 localities belong to the group of 1st class roads included in European system (AGR agreement); next 16 are at the group of other 1st class roads and the last group (12 localities) covers the roads of 2nd and 3rd class. The set of sixteen localities on the Czech territory consists of original 11 ones from previous similar research (Ván̆a et al., 2012) which has been expanded by five other places where are known migration corridors (see map in Romportl et al., 2017). There was total of 22 localities in Slovakia of which 7 are hot-spots proposed by Bojda et al. (2012) and two more ones came from older research by Kalaš (2014). The rest localities were added on the basis of the recommendation from nature conservation experts from ŠOP SR (National Park Nízke Tatry and Landscape Protected Area Kysuce) according to their local knowledge and known cases of wildlife-vehicle collisions between passing vehicles and large carnivores.

\section{Traffic survey}

Mobile automatic traffic counters were intended for carrying out traffic survey in a continuous manner in each locality. The time range of each measurement was at least 168 hours and consisted of 5 working days, one Saturday and one Sunday. The measurement season lasted from September to October 2017. All vehicles passing on the road were recorded by vehicle detection device Sierzega SR4. Detector of this device - radar - works at the base of Doppler's effect. Information on each vehicle was recorded including its driving direction, date and time, vehicle category and travel speed. Devices were mounted on the road sign pole in the suitable section of particular road (straight sections of road without crossroads or road retarders). All measurement sites except one were chosen on two-lane roads where one device was enough to cover the measurement in both directions. Only on the locality Žilina (Hričovská), there was four-lane road and thus, two devices had to be used (one per each direction).

The most important traffic characteristics were determined including the overall traffic volume per day and the daily variation of traffic (the percentage share of individual hourly interval on average daily traffic volume calculated from seven days of measurement) which are split into categories of vehicles (Figure 2).

The traffic intensity is presented in the form of general traffic-engineering characteristic called Annual Average Daily Traffic (AADT) intensity (Bartuška et al., 2016). It is expressed as the number of vehicles that has passed through a given section of the road in 24 hours and represents the average value for all days of the year including weekends or periods with lower intensity of traffic (winter). The measured traffic intensity was recalculated to AADT with the help of coefficients from official methodology approved by Ministry of Transport (Bartoš, 2012). 
Figure 2: Road traffic near Strelenka at the border between CZ and SK (site nr. 17)

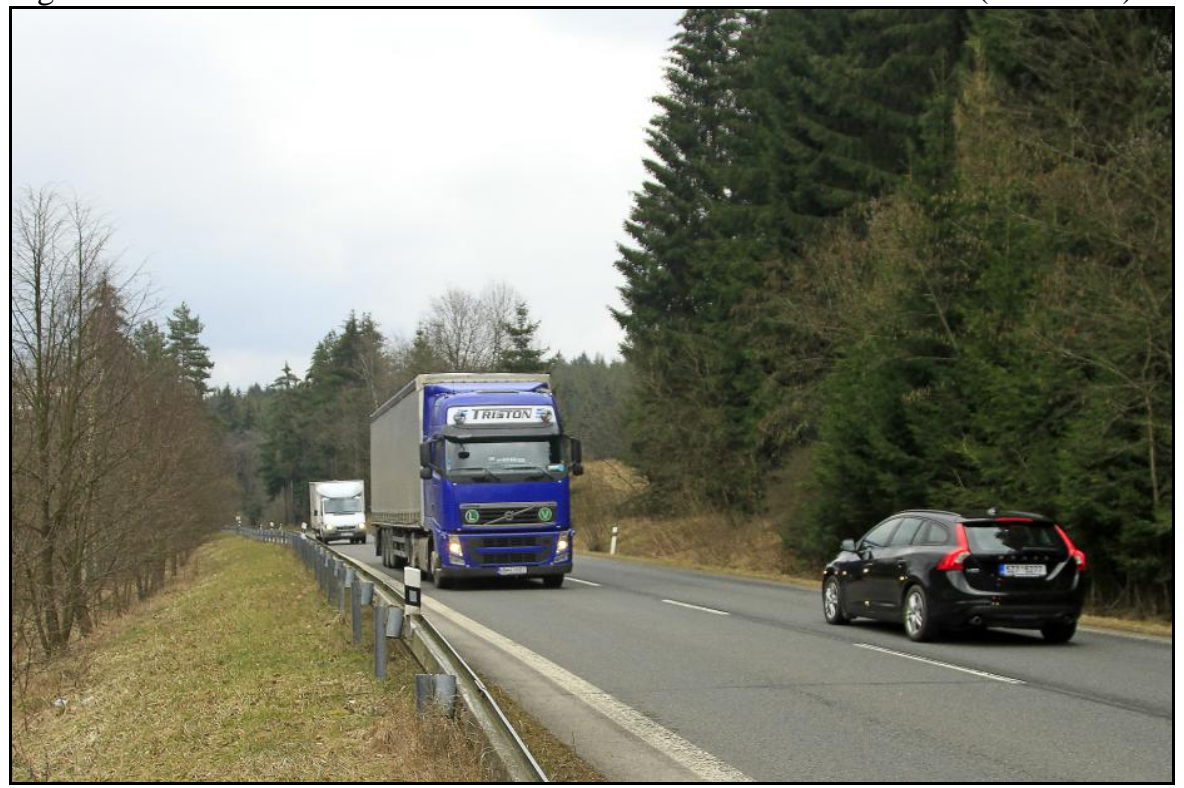

Author: Ivo Dostál

\section{Evaluation of road permeability for wildlife}

Probably the most important characteristic for evaluation of road's permeability for wildlife is the information on the time gap between two consecutive vehicles. Jacobson et al. (2016) presented the concept of four basic categories for behaviour of wildlife species near rush roads; the large carnivores can be considered as "avoiders", who recognize moving vehicles as threats and respond by avoiding the road. Based on previous experience and methodologies (Váňa et al., 2012; Martolos, Anděl, 2013) to keep results comparable, a total of 12 categories was determined in which the overall number and the relative frequency of defined intervals of time gaps were calculated in accordance with individual hour of the day. Time gaps between vehicles were rounded to nearest second to enable define following categories: 0-2 sec; 3-5 sec; 6-10 sec; $11-15 \mathrm{sec} ; 16$ - 20 sec; 21 - $30 \mathrm{sec} ; 31$ - $40 \mathrm{sec} ; 41-60 \mathrm{sec} ; 61-120 \mathrm{sec} ; 121-300 \mathrm{sec}$; more than $300 \mathrm{sec}$.

Special attention was paid to the data recorded during night i.e., in time when the wild animals are the most active. With respect to the season and the geographical location of the model area, for the night-time were considered hours within the range from $7 \mathrm{pm}$ to 6 am of Central-European Summer Time $(\mathrm{GMT}+2)$. 
Another characteristic calculated for each locality was the probability of time gap between two vehicles which was calculated separately for day and night time.

For assessment of the overall permeability was preferred the new approach: four classes were defined (Table 1) on base of the time gap recorded between two following vehicles. The definition of classes is derived in terms of events that may occur during a random attempt of animals to cross the road in relation to the passing vehicle.

Table 1: Classes of permeability and their definitions

\begin{tabular}{|c|l|l|}
\hline Class & Probable event & Description \\
\hline 4 & killed & $\begin{array}{l}\text { Immediate risk of the animal-vehicle collision and } \\
\text { probable road-kill. }\end{array}$ \\
\hline 3 & disturbed & $\begin{array}{l}\text { Strong disturbance of the animal by noise and } \\
\text { lighting from passing vehicle. }\end{array}$ \\
\hline 2 & repelled & $\begin{array}{l}\text { Previous occurrence of disturbances discourages } \\
\text { the animal from the crossing the road }\end{array}$ \\
\hline 1 & permeable & $\begin{array}{l}\text { Sufficient time gap between two following } \\
\text { vehicles enables the safe and undisturbed cross of } \\
\text { the road. }\end{array}$ \\
\hline
\end{tabular}

Calculation of permeability class was done independently for each of 604800 seconds of monitoring period in each locality according to recorded passages of vehicles during the measurement (further referred as "event") with following rules:

- the second when event occurred is categorized as Class 4

- 4 seconds before and 10 after the event are classified as Class 3

- from 11 th to 40th second after the event corresponds to Class 2

- over 40 second are defined as Class 1

- always the highest calculated class for each second is taken into account

Figure 3: The sample of calculation of permeability classes in situation with first vehicle passed at the 5 th second of the first minute, then time gaps between following vehicles, in seconds): 58, 6, 25, 1, 7, 172, 55 and 29.

\begin{tabular}{|c|c|c|c|c|c|c|c|c|c|c|c|c|c|c|c|c|c|c|c|c|c|c|c|c|c|c|c|c|c|c|c|c|c|c|c|c|c|c|c|c|c|c|c|c|c|c|c|c|c|c|c|}
\hline \multirow[b]{2}{*}{$1 . \mathrm{min}$} & \multirow{2}{*}{\multicolumn{3}{|c|}{\begin{tabular}{|l|l|}
1 & 2 \\
3 & 3 \\
\end{tabular}}} & \multirow{2}{*}{\multicolumn{3}{|c|}{\begin{tabular}{l|l|l|l|}
4 & 5 & 6 & 7 \\
\end{tabular}}} & \multirow{2}{*}{\multicolumn{2}{|c|}{ 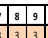 }} & \multirow{2}{*}{\multicolumn{2}{|c|}{\begin{tabular}{|l|l|}
10 & 11 \\
3 & 3 \\
\end{tabular}}} & \multirow{2}{*}{\multicolumn{3}{|c|}{\begin{tabular}{|l|l|l|}
12 & 13 & 14 \\
3 & 3 & 3 \\
\end{tabular}}} & \multirow{2}{*}{\multicolumn{2}{|c|}{\begin{tabular}{|c|c|c|}
15 & 16 & 17 \\
3 & 2 & 2 \\
\end{tabular}}} & \multirow{2}{*}{\multicolumn{3}{|c|}{ 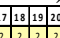 }} & \multirow{2}{*}{\multicolumn{2}{|c|}{\begin{tabular}{|l|l|l|}
2 & 21 & 22 \\
2 & 2 & 2 \\
\end{tabular}}} & & & \multirow{2}{*}{\multicolumn{3}{|c|}{\begin{tabular}{|l|l|l|}
26 & 27 & 28 \\
2 & 2 & 2 \\
\end{tabular}}} & \multirow{2}{*}{ 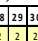 } & \multirow{2}{*}{\multicolumn{2}{|c|}{\begin{tabular}{|l|l|}
31 & 32 \\
2 & 2 \\
\end{tabular}}} & \multicolumn{3}{|c|}{\begin{tabular}{|l|l|l|}
33 & 34 & 35 \\
\end{tabular}} & \begin{tabular}{|l|l|}
36 & 37 \\
\end{tabular} & \multicolumn{2}{|c|}{\begin{tabular}{|l|l|}
38 & 3 \\
\end{tabular}} & \begin{tabular}{|l|l|l|}
9 & 40 & 4 \\
\end{tabular} & \multicolumn{2}{|c|}{$\begin{array}{ll}41 & 42 \\
\end{array}$} & \begin{tabular}{|l|l|}
43 & 44 \\
\end{tabular} & 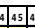 & \begin{tabular}{|l|l}
46 & 4
\end{tabular} & & & 50 & & & & & & & & 960 \\
\hline & & & & & & & & & & & & & 3 & & & & & & & & & & & & & & & & 2 & & 2 & 2 & 2 & 2 & 2 & 2 & \begin{tabular}{l|l}
2 & 2 \\
\end{tabular} & \begin{tabular}{|l|l|}
2 & 2 \\
\end{tabular} & 2 & 1 & \begin{tabular}{l|l|}
1 & 1 \\
\end{tabular} & 1 & 1 & 1 & 1 & 1 & \begin{tabular}{l|l}
1 & 1
\end{tabular} & 1 & 1 & 1 & 3 \\
\hline 2. $\mathrm{min}$ & 3 & 3 & & 3 & 3 & \begin{tabular}{l|l}
3 & 3 \\
\end{tabular} & 3 & 3 & 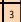 & 3 & 3 & 3 & 3 & 3 & 2 & 2 & 2 & 2 & 2 & \begin{tabular}{|l|l}
2 & 2 \\
\end{tabular} & 2 & 2 & 2 & 2 & 2 & \begin{tabular}{l|l}
2 & 3 \\
\end{tabular} & 3 & 3 & 3 & & 3 & 3 & 3 & 3 & 3 & 3 & \begin{tabular}{l|l}
3 & 3 \\
\end{tabular} & \begin{tabular}{|l|l|}
3 & 3 \\
\end{tabular} & 3 & 3 & \begin{tabular}{l|l}
3 & 3 \\
\end{tabular} & 3 & 3 & 3 & 3 & \begin{tabular}{|l|l}
2 & 2 \\
\end{tabular} & 2 & 2 & 2 & 2 & 2 \\
\hline $3 . \mathrm{min}$ & 2 & 2 & 2 & 2 & 2 & 22 & 2 & 2 & 2 & 2 & 2 & 2 & 2 & 22 & 2 & 2 & 2 & 2 & 2 & \begin{tabular}{|l|l|}
2 & 1 \\
\end{tabular} & 1 & 1 & 1 & 1 & 1 & 1 & 11 & 1 & 1 & 1 & 1 & 11 & 1 & \begin{tabular}{|l|l|} 
& \\
\end{tabular} & 1 & 1 & \begin{tabular}{l|l|}
1 & 1 \\
\end{tabular} & \begin{tabular}{|l|l|}
1 & 1 \\
\end{tabular} & 1 & 1 & \begin{tabular}{l|l|}
1 & 1 \\
\end{tabular} & 1 & 1 & 1 & 1 & \begin{tabular}{|l|l}
1 & 1 \\
\end{tabular} & \begin{tabular}{l|l|}
1 & 1 \\
\end{tabular} & 1 & \begin{tabular}{l|}
1 \\
\end{tabular} & 1 & 1 \\
\hline 4. $\mathrm{min}$ & 1 & 1 & 1 & 1 & 1 & 11 & 1 & 1 & 3 & 3 & 3 & 3 & 4 & 3 & 3 & 3 & 3 & 3 & 3 & \begin{tabular}{|l|l|}
3 & 3 \\
\end{tabular} & \begin{tabular}{l|l|}
3 & 3 \\
\end{tabular} & 2 & 2 & 2 & 2 & \begin{tabular}{l|l}
2 & 2 \\
\end{tabular} & 22 & 2 & 2 & 2 & 2 & 22 & 2 & \begin{tabular}{|l|l|}
2 \\
\end{tabular} & 2 & 2 & \begin{tabular}{l|l}
2 & 2 \\
\end{tabular} & $\begin{array}{ll}2 & 2 \\
\end{array}$ & 2 & \begin{tabular}{|l|l}
2 & 2 \\
\end{tabular} & \begin{tabular}{l|l}
2 & 2 \\
\end{tabular} & 2 & 2 & 2 & 2 & \begin{tabular}{|l|l}
2 & 2 \\
\end{tabular} & \begin{tabular}{l|l}
2 & 1 \\
\end{tabular} & & 1 & 1 & 1 \\
\hline $\min$ & 1 & 1 & 1 & & 3 & 3 & 3 & & 3 & 3 & 3 & \begin{tabular}{|l|l}
3 & \\
\end{tabular} & \begin{tabular}{l|l}
3 \\
\end{tabular} & \begin{tabular}{l|l}
3 \\
3
\end{tabular} & 3 & 3 & 3 & 2 & 2 & \begin{tabular}{|l|l|}
2 & 2 \\
\end{tabular} & \begin{tabular}{l|l}
2 & 2 \\
\end{tabular} & 2 & 2 & \begin{tabular}{|l|}
2 \\
\end{tabular} & 12 & \begin{tabular}{l|l|}
2 & 2 \\
\end{tabular} & 22 & 2 & \begin{tabular}{|l|l|}
2 \\
\end{tabular} & 3 & \begin{tabular}{l|l}
3 & 3 \\
3
\end{tabular} & 3 & & & 3 & 3 & \begin{tabular}{|l|l|}
3 & 3 \\
\end{tabular} & \begin{tabular}{|l|l|}
3 & 3 \\
\end{tabular} & 3 & \begin{tabular}{|l|l|}
3 & 3 \\
\end{tabular} & \begin{tabular}{l|l|}
3 & 3 \\
\end{tabular} & & 2 & 2 & & & & & & & 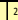 \\
\hline
\end{tabular}


Data processing was performed using set of own single-purpose scripts written in the text manipulation language awk in the cygwin environment.

\section{Results}

From the comparison of measured traffic intensities with the numbers published in the results of National Traffic Censuses (NTC), which took place in 2015 in Slovakia (SSC, 2016) and one year later in the Czech Republic ( $\check{R} S D$, 2017) is visible that the results of measured traffic are mostly lower - total of 23 localities has measured AADT lower than are the results of NTC while in 15 localities the higher traffic was recorded. The difference is visible especially in the Czech part of model area, which could be caused by the time of measurement as September's date was located in the second half of month, when high recreational season is already over in Beskydy mountains. Some localities (namely I/57 Lidečko and I/49 Strelenka) were affected by construction works on the roads (traffic-lights controlled shuttle traffic section due to reconstruction of bridges), which can cause the change in the travel behaviour (another route choice) and queuing of vehicles could have also negative impact on the correct functioning of detection device, especially in the peak time. Due to the construction of railway tunnel the road II/507 was closed between Kúpel'e Nimnica and Udiča from Saturday $8 \mathrm{am}$ to Sunday $6 \mathrm{pm}$. Only local traffic to Udiča village remained on the road so also this result is strongly affected by external circumstances. On the other hand there were 6 localities with the rise of traffic higher than $10 \%$.

In the season of measurement the dark part of the day was approximately between $7 \mathrm{pm}$ and $6 \mathrm{am}$. This time is crucial for wildlife activity. The share of traffic in this time was between 13 and $28 \%$.

There were four permeability classes for each locality defined according to the recorded time of vehicle passages and calculated gaps between them. The comparison of permeability in all 38 localities hour-by-hour is available in Figures 3-5. The difference between night-time and day-time is clearly visible. Only localities Uzgruň $(\mathrm{AADT}=947)$ and Solanec $(\mathrm{AADT}=1463)$ reached at least $50 \%$ share of time in highest permeability class. Most of localities is practically impermeable during the day. On the other hand, in the time between $11 \mathrm{pm}$ and 4am only five localities does not reach $50 \%$ share, others have mostly between $70 \%$ and $95 \%$, thus could be considered as relatively well permeable. The locality Žilina (Hričovská) never reach more than $10 \%$, so it is practically impermeable. Other localities with very limited permeability are Strečno, Ratkovo and Kysucký Lieskovec. Not surprisingly, all of these roads are among the main routes of the long-distance transport and are included in the system defined by European Agreement on Main International Traffic Arteries (so called "AGR agreement") developed by the United Nations Economic Commission for Europe (UNECE). 
Figure 4: Wildlife permeability in researched localities

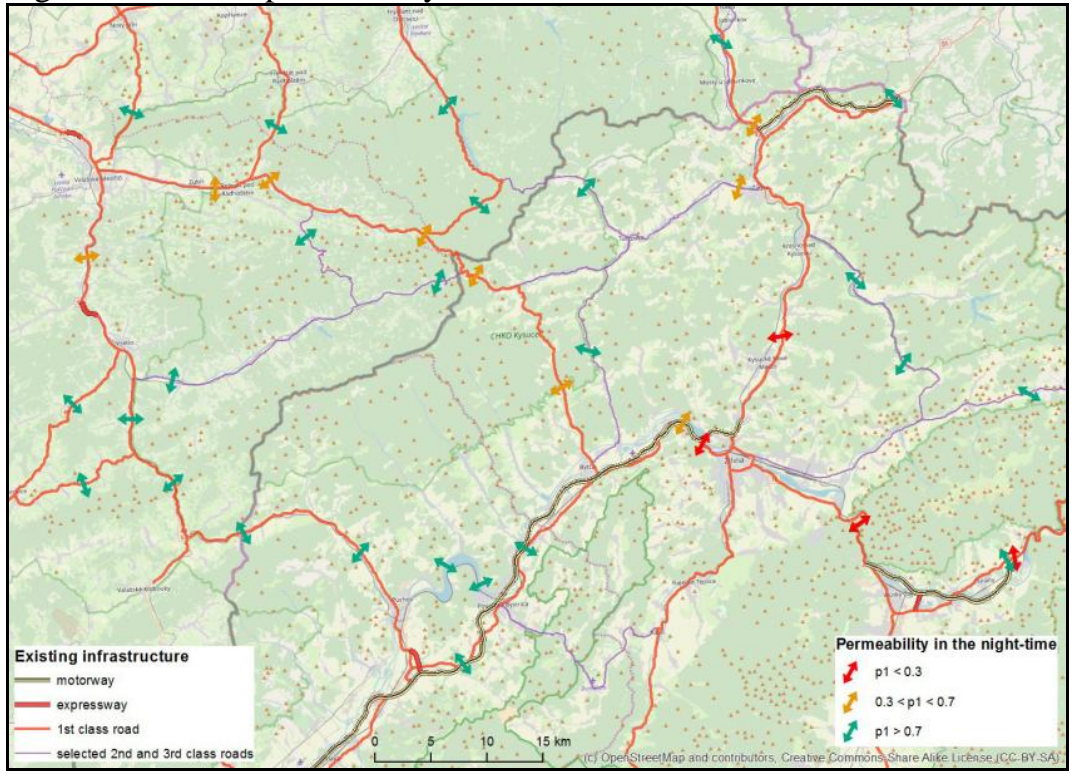

Source: authors' own work; background map: COpenStreetMap

Figure 5: Share of time classified in class 1 (permeable) by hour of day at localities of first-class roads included to European system (AGR)

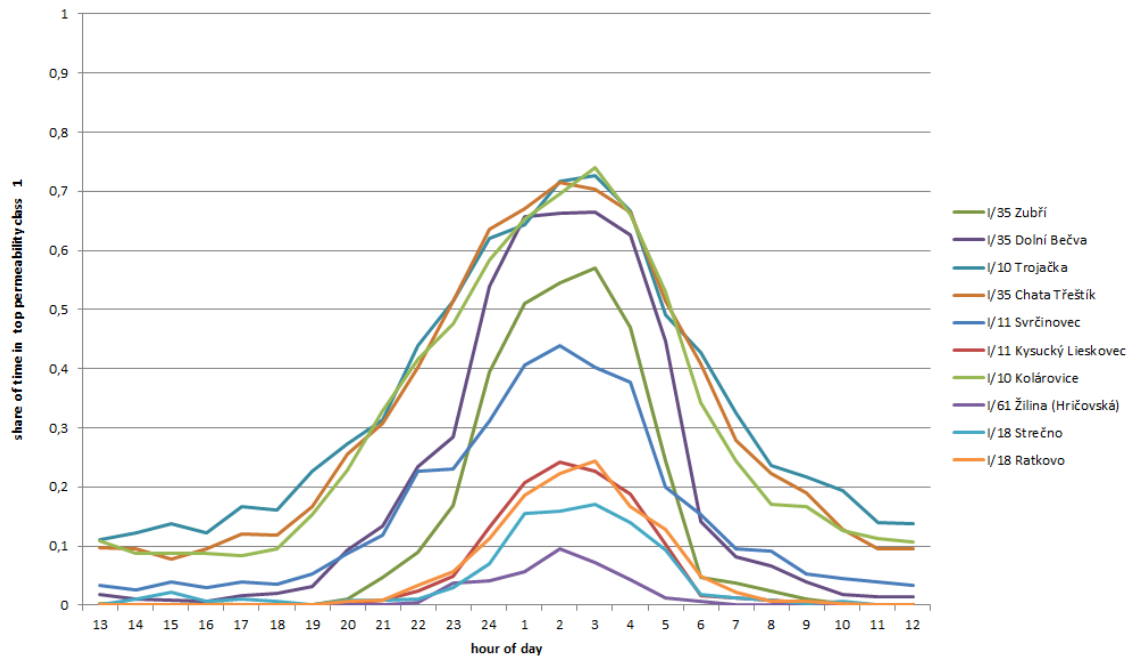

Source: authors' own work 
Figure 6: Share of time classified in class 1 (permeable) by hour of day at localities of first-class roads outside the European system (AGR)

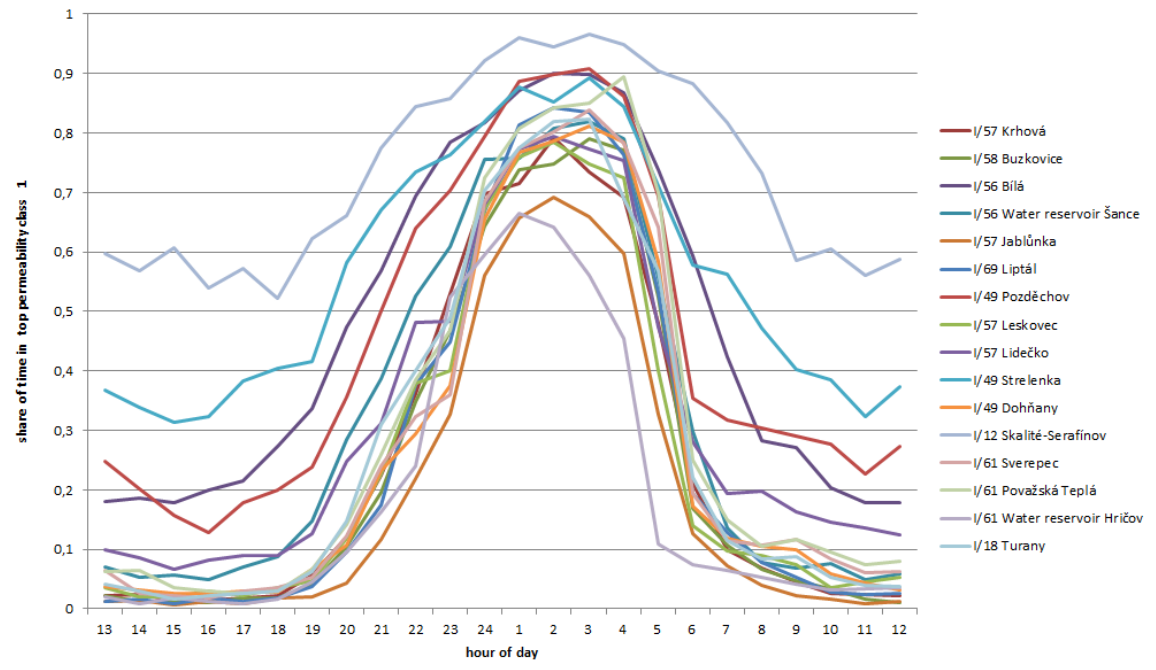

Source: authors' own work

Figure 7: Share of time classified in class 1 (permeable) by hour of day at localities of second and third class roads

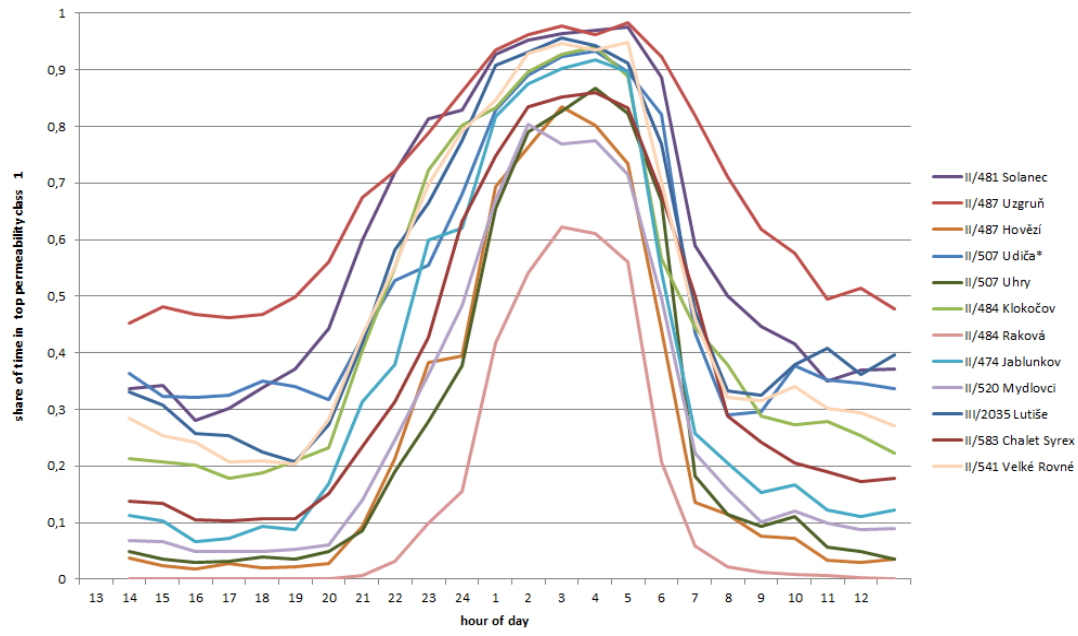

* results affected by week-end closure of road due to construction of railway relocation

Source: authors' own work 


\section{Comparison to the results of previous measurements}

The 13 localities were evaluated also by Ván̆a (2012) or Kalaš (2014). The previous researches using manual counting were limited only to one workday, so from current data was only the mean from Tuesdays and Thursdays data calculated to keep traffic intensities comparable to older results. The traffic intensity has increased in most locations. According to the statistics, the transport performance of the whole Czech Republic meanwhile increased by $12 \%$ in personal individual transport and drop by $1,5 \%$ in the freight road transport (MD, 2017). The higher than expected growth was recorded in the locality \#13 on the road I/69 between Zlín and Vsetín - traffic increased by $43 \%$ there. This place of measurement was affected by construction works on the road between Vsetín and Horní Lideč so drivers probably preferred this route to avoid delays due to shuttle-traffic sections. Another locality with significant increase of traffic was \#6 II/487 Uzgrun̆, but in this place remains the traffic flow relatively low as the intensity is still under 1000 vehicles per day. The significant increase was recorded also in locality \#38 Ratkovo, which is affected by new section of D1 motorway opened in 2015.

Váňa (2012) defined his own methodology to assess the permeability according to the time gaps between individual vehicles during night hours from $9 \mathrm{pm}$ to 5am, when increased activity and frequent movements of large mammals is expected and presented the overall permeability of road index which can take values between 1 (worst, non-permeable road) and 4 (best, fully permeable road). Obtained results from radars were recalculated also according to this previous methodology to compare the results.

The comparison of results shows similar results with previous research. The final overall permeability of road index remained essentially the same for all communications compared. The significantly lower value of index was recorded in localities I/58 Buzkovice (drop from 3,20 to 3,04) and II/484 Klokočov (drop from 3,75 to 3,53), while certain improvement is clear in most traffic affected localities Svrčinovec (from 2,24 to 2,41) and in Bumbálka pass (from 2,75 to 2,92). The findings for two localities evaluated in Slovakia was that in I/18 Ratkovo the permeability remained very bad (with index equal to 1,35 ) while at II/583 Rovná hora pass the situation improved (index rose from 1,88 to 2,12).

The share of permeability classes in the relation to the traffic intensity (Figure 7 ) in the $\mathrm{p} 2+\mathrm{p} 3$ category (avoided, disturbed animals) confirms the results presented in the framework by Jacobson et al. (2016) for the "avoiders" group of ungulates with the maximum limit near 35000 vehicles per day. 
Figure 8: Relation between traffic intensity and the share of permeability classes

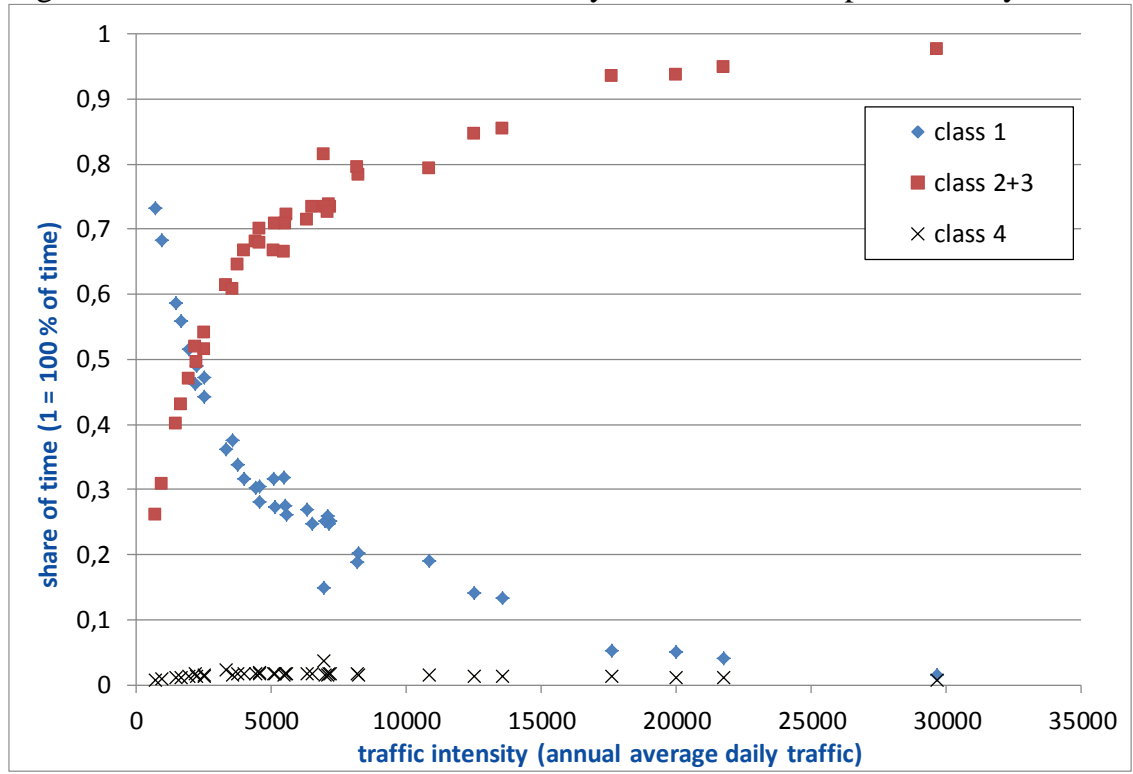

Source: authors' own work

\section{Conclusion}

The results of the time gaps analysis are good indicator for assessment of the barrier effect of road at specific locations. It can provide general view on road permeability in different times of day. The results can be used in the proposals of measures to reduce mortality and barrier effect of road.

Each vehicle passage was recorded for 168 hours using the Sierzega SR-4 radar in each of 38 model localities. Subsequently the patterns of traffic intensity over time of day were analysed from obtained data were on the basis of gaps between individual records. Four categories of permeability were proposed to represent the predicted behaviour of the animal in relation to the traffic (class 1 permeable, class 2 - repelled, class 3 - disturbed, class 4 - collision and probable road-kill). The entire 168-hour timeline was divided into 604800 second sections, each of which was assigned one of four categories depending on its position in relation to the passage of individual vehicles on the basis of several rules. The class 1 was defined as at least 4 seconds prior and at least 40 seconds after the nearest vehicle passage. In the case of several vehicle passages in time less than 45 seconds, the highest class always belongs to each second. The share of the individual categories in the total time is then the final evaluation of the road in terms of its permeability split by individual hours of the day. 
The results confirmed that the worst permeability can be expected for the 1 st class roads included in the European system. Especially during working days, traffic does not stop even on the late night, and the busiest roads are permeable in less than $25 \%$ of the time. In the daytime, the intensity is so high that there is no way to expect any permeability. For less busy roads, only these with calculated intensity around 1500 vehicles and less (AADT) were classified as permeable in at least $40 \%$ of the time during the day-time (Figure 6). On the other hand, during the late night, traffic was significantly calming down and all roads outside the European system reached share of permeable time at least $60 \%$.

Another comparison was done against results of older measurements done at 13 localities covered by previous researches of Váňa (2012) and Kalaš (2014). The calculated index of permeability of road based on gaps distribution remained essentially the same for most localities compared. The significantly lower value of index was recorded in localities Buzkovice and Klokočov, while certain improvement is clear in most traffic affected localities - Svrčinovec and Bumbálka pass. The findings for two localities evaluated in Slovakia was that in Ratkovo the permeability remained the same while at Rovná hora pass the situation improved.

\section{Acknowledgement}

This article was produced within the Transgreen project (Interreg Danube programme; no. DTP1-187-3.1-TRANSGREEN) on research infrastructure acquired from the Operation Programme Research and Development for Innovations (CZ.1.05/2.1.00/03.0064).

\section{References}

ANDĚL, P. - GORČICOVÁ, I. - PETRŽILKA, L. V BELKOVÁ, H. 2010. Landscape fragmentation caused by traffic in the Czech Republic: Evolution from the year 1980 and the prognosis till 2040. In $10^{\text {th }}$ International Multidisciplinary Scientific Geoconference and EXPO - Modern Management of Mine Producing, Geology and Environmental Protection, SGEM 2010, vol. 2. Varna (Bulgaria), 20 - 26 June 2010, pp. 651-656. ISBN 978-954918181-4. ANDĚL, P. 2013. Landscape Fragmentation Caused by Traffic and its Impact on Wildlife Migration. In Životné prostredie. ISSN 0044-4863, 2013, roč. 47, č. 2, s. 90-94.

BARTOŠ, L. 2012. TP 189 - Stanovení intenzit dopravy na pozemních komunikacích. Technické podmínky. II. vyd. Plzeň: EDIP, 2012. 76 s. ISBN 978-80-87394-06-9. (in Czech)

BARTUŠKA, L. - BIBA, V. - JEŘÁBEK, K. 2016. Verification of Methodical Procedure for Determining the Traffic Volumes Using Short-term Traffic Surveys. In Procedia Engineering. vol. 161, pp. 275-281. 
BOJDA, M. - PAVLIŠIN, I. - DRENGUBIAK, P. - KALAŠ, M. et al. 2012. Vymedzenie a ochrana migračných koridorov pre vel' ké šelmy v Západných Karpatách (NP Malá Fatra, CHKO Kysuce, CHKO Beskydy). In Kutal M. /ed./ Velké šelmy a jejich migračni koridory v Západnich Karpatech: Malá Fatra Kysucké Beskydy - Moravskoslezské Beskydy - Javorniky. Olomouc: Hnutí DUHA, s. 27-33. ISBN 978-80-904530-3-6. (in Slovak)

DOSTÁL, I. - ANDĚL, P. V HAVLÍČEK, M. 2018. New Maps of the Transport Infrastructure's Impact on Biodiversity. In Lněnička, L. (ed.) Proceedings of 25th Central European Conference Useful Geography: Transfer from Research to Practice. Brno, October 12-13, 2017. Brno: Masaryk univerzity, 2018. pp. 259-269. ISBN 978-80-210-8908-2.

CHAPRON, G. - KACZENSKY, P. - LINNELL, J. D. C. et al. 2014. Recovery of large carnivores in Europe's modern human-dominated landscapes. In Science. vol. 346, pp. 1517-1520. DOI: 10.1126/science.1257553.

IUELL, B. - BEKKER, G. J. - CUPERUS, R. et a., 2003. Wildlife and Traffic: A European Handbook for Identifying Conflicts and Designing Solutions. Bruseles: KNNV Publishers, 2003.

JACOBSON, S. L. - BLISS-KETCHUM, L. L. - de RIVERA, E. E. - SMITH, W. P. 2016. A behavior-based framework for assessing barrier effects to wildlife from vehicle traffic volume. In Ecosphere. vol. 7, no. 4. DOI: $10.1002 /$ ecs2.1345.

KALAŠ, M. 2014. Dopravné kolízie s medved’om hnedým (Ursus arctos L.) a priepustnost' vybraných cestných komunikácií v oblasti Národného parku Malá Fatra. In Kutal M., Suchomel, J. (eds.) Analýza výskytu velkých šelem a průchodnosti krajiny v Západnich Karpatech. Brno: Mendelova univerzita, s. 10-13. (in Slovak)

KAPHEGYI, T. A. M. - DEES, M. - ZLATANOVA, D. et al. 2013. Rapid assessment of linear transport infrastructure in relation to the impact on landscape continuity for large ranging mammals. In Biodiversity and Conservation. vol. 22, article number 153.

KUSAK, J. - HUBER, D. - GOMERCIC, T. - SCHWADERER, G. - GUZVICA, G. 2009. The permeabillity of highway in Gorski kotar (Croatia) for large mammals. In European Journal of Wildlife Research. vol. 55, pp. 7-21.

MARTOLOS, J. - ANDĚL, P. 2013. Distances between Vehicles in traffic Flow and the Probability of Collision with Animals. In Transactions on Transport Sciences. ISSN 1802-971X, 2013, vol. 6, no. 2, pp. 97-106. DOI: 10.2478/v10158-012-0036-x.

ROMPORTL, D. (ed.) - ZÝKA, V. - SKOKANOVÁ, H. - HLAVÁČ, V. et al. 2017. Atlas fragmentace a konektivity terestrických ekosystémů v České republice. Praha: AOPK ČR. ISBN 978-80-88076-50-6. (in Czech)

ŘSD. 2017. Celostátní sčitání dopravy 2016. Available online from <http://scitani2016.rsd.cz/pages/informations/default.aspx> (cit. 2017-12-05) 
SSC. 2016. Celoštátne sčítanie cestnej dopravy v roku 2015. Available online from $<$ http://www.ssc.sk/sk/cinnosti/rozvoj-cestnej-siete/dopravneinzinierstvo/celostatne-scitanie-dopravy-v-roku-2015.ssc> (cit. 2017-12-05)

VÁŇA, M. - STÝSKALA, J. - BOJDA, M. - KUTAL, M. 2012. Propustnost silničních komunikací na významných migračních koridorech v oblasti CHKO Beskydy. In Kutal, M. (ed.) Velké šelmy a jejich migračni koridory $v$ Západních Karpatech: Malá Fatra - Kysucké Beskydy - Moravskoslezské Beskydy - Javorniky. Olomouc: Hnutí DUHA, s. 17-22. ISBN 978-80-9045303-6. (in Czech)

\section{Mgr. Ivo Dostál}

Centrum dopravního výzkumu, v. v. i. (Transport Research Centre)

Líšeňská, 33a, 63600 Brno

E-mail: ivo.dostal@cdv.cz

\section{Ing. Josef Svoboda}

Centrum dopravního výzkumu, v. v. i. (Transport Research Centre)

Líšeňská, 33a, 63600 Brno

E-mail: josef.svoboda@cdv.cz

\section{Ing. Pavel Pohorský}

Centrum dopravního výzkumu, v. v. i. (Transport Research Centre)

Líšeňská, 33a, 63600 Brno

E-mail: pavel.pohorsky@cdv.cz

Mgr. Marek Havlíček, Ph. D.

Centrum dopravního výzkumu, v. v. i. (Transport Research Centre)

Líšeňská, 33a, 63600 Brno

E-mail: marek.havlicek@cdv.cz 